\title{
Uji Aktivitas Lektin Biji Kebiul terhadap Kecepatan Penggumpalan Sel Darah Merah Manusia dalam Kondisi Patologis dan Implementasinya sebagai Modul Pembelajaran Kimia
}

\author{
Yeni Trianah \\ Fakultas Teknik, Universitas Musi Rawas, Sumatera Selatan \\ Email: trianah.yeni@yahoo.com
}

\begin{abstract}
[Lectin activities of kebiul seeds to the red blood cell agglutination speed in pathological condition and its implementation as a chemical learning module]. The purposes of this research were to determine: 1) the relative moleculer mass protein that behaves as a lectin in the seed extract kebiul, 2) the velocity of red blood cell clumping influenced by seed lectin kebiul, 3) know the difference student results on protein taught modules and a without modules taught at the College of Teacher Training and Education Teachers Association of the Republic of Indonesia (STKIP-PGRI) Lubuklinggau. Extraction of seeds Kebiul carried out in the a cold buffer solution with pH 7.4 and plus $60 \%$ saturated ammonium sulfat (salting out method), and made in four concentrations, namely: $2 \%, 4 \%, 6 \%$ and $8 \%$. Then tested the activity of seed lectin kebiul to speed clotting of human red blood cells in pathological conditions. To determine the relative molecular mass protein that behaves as a lectin in the seed extract kebiul SDS PAGE electrophoresis performed 1-D. The experiment were then implemented on the material of protein biochemistry using modules. The results of the research showed that on the concentration of $8 \%$ the velocity of the clumping of a human red blood cells hypertension most of the highest, the relative molecular mass which behaves as a lectin protein electrophoresis results of 1-D SDS PAGE obtained by a three protein bands in the range of moleculer weights 80, 128 and $144 \mathrm{kDa}$. The Results of the implementation of the experimental class showed an average 'post test value was 95 and the post test control class 69.41. There are differences in students' learning about protein for students who are taught by module and who are taught without module.
\end{abstract}

Keywords: Lectin; agglutination; blood; 1-D SDS PAGE; learning outcomes.

\begin{abstract}
ABSTRAK
Penelitian ini bertujuan untuk: 1) mengetahui massa molekul ralatif protein yang berperilaku sebagai lektin dalam ekstrak biji kebiul, 2) mengetahui kecepatan penggumpalan sel darah merah yang dipengaruhi oleh lektin biji kebiul, 3) mengetahui perbedaan hasil belajar mahasiswa tentang protein yang diajarkan dengan modul dan yang diajarkan tanpa modul di Sekolah Tinggi Keguruan dan Ilmu Pendidikan Persatuan Guru Republik Indonesia (STKIP-PGRI) Lubuklinggau. Ekstraksi biji kebiul dilakukan dalam larutan buffer dingin dengan $\mathrm{pH} 7,4$ dan ditambah ammonium sulfat jenuh $60 \%$ (metode salting out), serta dibuat dalam empat konsentrasi, yaitu : 2\%, 4\%, 6\% dan 8\%. Kemudian dilakukan uji aktifitas lektin biji kebiul terhadap kecepatan penggumpalan sel darah merah manusia dalam kondisi patologis. Untuk menentukan massa molekul relatif protein yang berperilaku sebagai lektin dalam ekstrak biji kebiul dilakukan elektroforesis SDS PAGE 1-D. Uji yang dilakukan, kemudian diimplementasikan pada pembelajaran biokimia materi protein dengan menggunakan modul. Hasil penelitian menunjukkan pada konsentrasi $8 \%$ kecepatan penggumpalan sel darah merah manusia hipertensi golongan A paling tinggi, massa molekul relatif protein yang berperilaku sebagai lektin hasil elektroforesis SDS PAGE 1D diperoleh 3 pita protein yang berada pada kisaran berat molekul 80, 128 dan $144 \mathrm{KDa}$. Hasil diimplementasi pada kelas eksperimen menunjukkan rata-rata nilai pos test 95 dan kelas kontrol 69,41. Terdapat perbedaan hasil belajar mahasiswa tentang protein pada mahasiswa yang diajarkan dengan modul dan yang diajarkan tanpa modul.
\end{abstract}

Kata kunci: Lektin; aglutinasi; darah; SDS PAGE 1-Dl; hasil belajar 


\section{PENDAHULUAN}

Lektin yaitu kelompok protein yang berinteraksi secara khas dengan karbohidrat. Lektin sendiri berupa molekul glikoprotein dan mekanisme pengikatannya terhadap karbohidrat berupa ikatan non kovalen. Ikatan ini memang lemah, tetapi jika terbentuknya lebih dari satu ikatan, baik antar molekul maupun dalam molekul lektin, maka cukup kuat untuk menggumpalkan sel (Alroy, 1988). Tanaman berkhasiat obat di telaah dan di pelajari secara ilmiah. Hasil penelitian mendukung bahwa tanaman obat memang memiliki kandungan zat-zat atau senyawa yang secara klinis terbukti bermanfaat bagi kesehatan. Tujuan penelitian adalah untuk mengetahui massa molekul relatif protein yang berpirilaku sebagai lektin terkandung dalam ekstrak biji kebiul yang dapat menggumpalkan sel darah merah manusia dalam kondosi patologis pada golongan darah A dan B dengan Eletroforesis SDS PAGE 1D. Ruang lingkup penelitian meliputi:

1. Sampel yang diekstraksi adalah biji kebiul yang merupakan tanaman golongan biji kacang-kacangan bentuknya bulat dengan diameter kurang lebih $1 \mathrm{~cm}$ jika sudah tua warna buah abu-abu.

2. Lektin merupakan suatu kelompok protein yang mempunyai daya afinitas tinggi terhadap gugus sakarida spesifik pada molekul glikolipid dan glikoprotein. Lektin dapat menyebabkan penggumpalan sel darah merah sebab dapat mengikat gugus sakarida pada permukaan sel darah merah.

3. Elektroforesis digunakan untuk menentukan massa molekul relative protein yang berperilaku sebagai lektin terkandung dalam ekstrak biji kebiul.

4. Uji aktivitas senyawa yang diekstraksi dilakukan pada sel darah merah manusia penderita penyakit malaria, diabetes, hipertensi dan asam urat.

5. Uji aktivitas lektin biji kebiul terhadap kecepatan penggumpalan sel darah merah dilakukan pada sel darah merah yang menggumpal setelah ditambah ekstrak biji kebiul

6. Kondisi patologis yaitu orang yang menderita penyakit dalam penelitian ini yaitu malaria, diabetes, hipertensi dan asam urat

7. Hasil penelitian di implementasikan sebagai sumber belajar kimia berbentuk
MODUL pada Mata Kuliah Biokimia materi senyawa metabolit primer khususnya protein untuk mahasiswa STKIP-PGRI Lubukinggau Prodi Biologi Semester IV Angkatan 2011.

\section{METODE PENELITIAN}

\section{Alat yang digunakan}

Eksperimen Laboratorium

Mikropipet $5 \mu \mathrm{l}$, pipet tipis T-200Y, tabung eppendot, alat sentrifuge, sarkal, mikroskop, beaker glass, labu pengencer, tabung reaksi, rak tabung reaksi, pipet $2 \mu \mathrm{L}, 5$ $\mu \mathrm{L}$ dan $10 \mu \mathrm{L}$, bola hisap, waterbath, batang pengaduk, kaca objek, timbangan analitik, spatula, jarum suntik, vortex mixer, baju laboratorium, kamera, tabung sampel, statif, dan seperangkat alat elektroforesis.

\section{Penelitian dan Pengembangan}

Pada penelitian ini digunakan Modul dan instrumen untuk mengukur hasil belajar kimia yang dikembangkan dalam bentuk tes

\section{Bahan}

\section{Bahan ekperimen laboraturium}

Bahan-bahan yang digunakan untuk penelitian di laboratorium adalah: biji kebiul, sampel darah manusia penderita malaria, diabetes, hipertensi dan asam urat, etanol 96\%, $50 \mathrm{mM}$ Tri S-HCI, 50mM NaHCO $3,10 \mathrm{mM}$ $\mathrm{MgCl}_{2} \cdot 6 \mathrm{H}_{2} \mathrm{O}, 5 \mathrm{mM} \mathrm{Na} \mathrm{S}_{2} \mathrm{O}_{3}, 5 \mathrm{mM}$ EDTA, amonium sulfat $60 \%$ dan $\mathrm{CuSO}_{4} 1 \%$ dan lainlain.

\section{Bahan untuk penelitian pembelajaran Silabus, RPP, Modul.}

Prosedur Penelitian Eksperimen Laboratorium Uji Pendahuluan

Uji pendahuluan dilakukan dengan menggunakan metode Biuret. Biji kebiul. dibuang kulitnya dan digiling kotiledon bijinya sehingga menjadi tepung. Ambil dengan spatula tepung tersebut masukkan dalam tabung reaksi tambahkan $2 \mathrm{~mL}$ larutan $\mathrm{NaOH}$ $0,1 \mathrm{M}$ dan teteskan CuSO4 $1 \%$ sampai terbentuk warna lembayung. Jika terbentuk warna lembayung, berarti dalam sampel tersebut positif mengandung protein. 


\section{Ekstraksi Lektin Biji kebiul}

Sampel biji kebiul. diambil dari Bengkulu selatan . Kebiul yang telah dipilih diambil sebanyak $20 \mathrm{~g}$ dibilas dengan akuades, dan digiling sehingga menjadi tepung (powder). Sebanyak 10 gram tepung tersebut dihomogenisasikan dalam $20 \mathrm{~mL}$ larutan buffer dingin dengan $\mathrm{pH} 7,4$ untuk homogenasi yang berisi $50 \mathrm{mM}$ Tris- $\mathrm{HCl}, 50$ $\mathrm{mM} \mathrm{NaHCO} 3,10 \mathrm{mM} \mathrm{MgCl} 2 \cdot 6 \mathrm{H}_{2} \mathrm{O}, 5 \mathrm{mM}$ $\mathrm{Na}_{2} \mathrm{~S}_{2} \mathrm{O}_{3} .5 \mathrm{H}_{2} \mathrm{O}$. Homogenasi dilakukan dengan Sharkal. Homogenasi disaring, cairan hasil saringan disentrifuse dengan kecepatan 4500 rpm selama 15 menit. Supernatan dipisahkan dari larutan lainnya. Pellet dibuang dan supernatan diambil, kemudian ditambahkan ammonium sulfat jenuh $60 \%$ (metode salting out) dalam tabung reaksi. Untuk memisahkan protein presipitasi dengan larutannya, maka tabung reaksi dimaksud disentrifugasi dengan kecepatan $14.000 \mathrm{rpm}$ selama 30 menit (Gegenheimer, 1990; Englard dan Seiffer, 1990).

\section{Pengambilan Sel darah merah}

Sampel darah diambil dari darah manusia. Darah relawan yang diambil adalah darah relawan penderita malaria, diabetes, hipertensi, dan asam urat. Masing masing darah tersebut diambil dan dimasukkan dalam tabung vaccucite yang telah berisi antikoagulan (EDTA).

Uji aktivitas ekstrak biji kebiul terhadap penggumpalan sel darah merah manusia dalam kondisi patologis

\section{Persiapan sel darah merah}

Darah diletakkan dalam tabung, disentrifuse pada kecepatan $2.500 \mathrm{rpm}$ selama 5 menit. Supernatan berupa plasma darah dibuang, sedangkan pellet terdiri dari sel-sel darah merah dan sel-sel darah putih dicuci dengan garam fisiologis $\mathrm{NaCl} 0,9 \%(\mathrm{w} / \mathrm{v})$. Pellet tambahkan $\mathrm{NaCl} 0,9 \%$ (w/v), kemudian disentrifugasi pada kecepatan $1500 \mathrm{rpm}$ selama \pm 2 menit. Pencucian darah dilakukan 3 kali. Pellet yang diperoleh digunakan untuk uji aktivitas lektin biji kebiul terhadap penggumpalan sel darah merah manusia dan uji aktivitasnya terhadap kecepatan penggumpalan sel darah merah tersebut.
Uji aktivitas ekstrak biji kebiul terhadap hemaglutinasi sel darah manusia dalam kondisi patologis.

Untuk pengujian hemaglutinasi dilakukan dengan cara $3 \mu \mathrm{L}$ darah merah diletakkan pada kaca objek ditambahkan $3 \mu \mathrm{L}$ larutan hayem dihomogenkan lalu ditambahakan $3 \mu \mathrm{L}$ ekstrak protein yang didapat dari hasil preparasasi campuran dihomogenkan lalu ditutup dg kaca penutup (cover glass), lalu diamati penggumpalan sel darah merah secara visual dengan bantuan mikroskop binukuler dengan kamera tambahan bantuan dinocapture dengan perbesaran $40 \mathrm{x}$ 10 dan 100 x 10 . Penggumpalan sel darah merah difoto dengan menggunakan kamera dinocapture yang telah di sambungkan dengan computer. Jika terjadi penggumpalan, berarti didalam ekstrak tersebut positif mengandung lektin. Pengujian dilakukan 5 kali.

Uji aktivitas lektin biji kebiul terhadap kecepatan penggumpalan sel darah merah manusia dalam kondisi patologis

Perlakuan untuk uji aktivitas lektin Kebiul terhadap kecepatan penggumpalan sel darah merah yaitu dilakukan dengan cara $3 \mu \mathrm{L}$ darah merah diletakkan pada kaca objek ditambahkan $3 \mu \mathrm{L}$ larutah hayem dihomogenkan lalu ditambahakan $3 \mu \mathrm{L}$ ekstrak protein dari pengenceran lektin (meliputi 4 konsentrasi, yaitu: 2\%, 4\%, 6\% dan $8 \%$ ) yang didapat dari hasil preparsasi campuran dihomogenkan lalu ditutup dengan kaca penutup (kaper glas), lalu diamati penggumpalan sel darah merah secara visual dengan bantuan mikroskop binukuler dg kamera tambahan bantuan dinocapture dengan $\begin{array}{llllllll}\text { perbesaran } & 40 & \mathrm{x} & 10 & \text { dan } & 100 & \mathrm{x} & 10 .\end{array}$ penggumpalan sel darah merah difoto dengan menggunakan kamera dinocapture yang telah di sambungkan dengan computer. Pengujian dilakukan 5 kali.

Penentuan massa molekul relatif dengan elektroforesis SDS PAGE 1-D

Di buat PAGE-bawah dan PAGE-atas keping dengan sejumlah sumur yang siap diisi sampel protein. Sampel protein kontrol dan perlakuan dengan konsentrasi sama dimasukkan ke dalam sumur. Standar protein yang dipakai pada analisis ini adalah pure whey dengan kriteria sebagai berikut : hight moleculer weight $141 \mathrm{kDa}$ whey protein, lactoperoxidase $(75 \mathrm{kDa})$, casein $(35 \mathrm{kDa}), \beta$ - 
lactoglobin (18 $\mathrm{kDa})$ dimasukkan kedalam sumur secara terpisah. Elektroforesis dilakukan pada tegangan konstan (120 atau $150 \mathrm{~V}$ ) dan dihentikan ketika warna pelacak (bromfenol biru) telah bergerak mencapai ujung bawah gel. PAGE 1-D yang dihasilkan kemudian diwarna dengan CBB R-250. PAGE 1-D dikeringkan dengan alat pengering gel (BioRad, 165-1740). Pita protein diamati dan difoto secara langsung menggunakan kamera digital. Jumlah komponen ditentukan dari banyaknya noda yang didapatkan dari hasil pemisahan. Untuk menunjukkan bahwa protein yang berperilaku sebagai lektin pada biji kebiul, maka hasil elektroforesis SDS PAGE 1-D dianalisis rentangan berat molekulnya.

\section{Prosedur Penelitian dan Pengembangan}

Penelitian ini dilakukan di dalam kelas atau indoor education. Pembelajaran indoor education ini dilakukan pada mahasiswa Prodi Biologi semester IV angkatan 2011. Penelitian dilakukan di 2 kelompok belajar yang berbeda. Kelompok belajar pertama dilakukan pembelajaran dengan menggunakan modul sebagai kelas eksperimen dan kelompok kedua sebagai kelompok kontrol yang tidak menggunakan modul dalam pembelajarannya, dimana masing-masing kelas menggunakan metode kontekstual. Penelitian menggunakan modul juga dilakukan oleh Latifah et al (2017) dan didapatkan hasil bahwa Terdapat peningkatan hasil belajar mahasiswa sebelum dan setelah menggunakan modul.

\section{HASIL DAN PEMBAHASAN}

\section{Hasil Penelitian Eksperimen Laboratorium Ekstraksi biji buah kebiul}

Untuk memperoleh senyawa protein yang terdapat dalam biji buah kebiul dilakukan dengan cara ekstraksi. Sebelum diekstraksi biji buah kebiul terlebih dahulu dilakukan uji identifikasi protein dengan uji biuret. Dari uji pendahuluan terbentuk warna ungu atau lembayung, hal ini menunjukkan bahwa di dalam biji buah kebiul tersebut positif mengandung protein. Warna ungu (lembayung) yang terbentuk pada iju biuret disebabkan karena biji buah kebiul mengandung ikatan peptida.

Proses ekstraksi dilakukan dengan cara menghomogenisasikan 10 gram tepung biji buah kebiul dalam larutan buffer dingin dengan $\mathrm{pH} 7,4$. Selanjutnya disentrifus untuk memisahkan supernatan protein dengan presipitat ekstrak kotor. Kemudian supernatan protein ditambahkan dengan ammonium sulfat, lalu disentrifus. Hasilnya terbentuk protein presipitasi yang akan digunakan untuk pengujian aktivitas terhadap penggumpalan sel darah merah.

Uji aktifitas ekstrak biji kebiul terhadap penggumpalan sel darah merah manusia dalam kondisi patologis

Uji aktifitas senyawa yang diperoleh dari ekstrak biji kebiul dilakukan pada darah manusia penderita malaria golongan darah $\mathrm{B}$, diabetes golongan darah $\mathrm{B}$, Hipertensi golongan darah $\mathrm{A}$, asam urat golongan darah A dan disimpan dalam botol vaccucite yang sudah berisi larutan EDTA (antikoagulan). Darah diletakkan dalam tabung, disentrifus dan dicuci 3 kali, pelet yang diperoleh digunakan untuk proses uji aktifitas ekstrak biji kebiul terhadap penggumpalan sel darah merah.

Satu tetes sampel darah ditambahkan dengan satu tetes larutan hayem untuk memisahkan sel darah merah dengan sel darah putih, dan ditambahkan satu tetes ekstrak biji kebiul diletakkan pada kaca preparat, kemudian dilakukan pengamatan dengan bantuan mikroskop binukuler dengan kamera tambahan bantuan dinocapture dengan perbesaran 100 x 10 dan penggumpalan sel darah merah difoto dengan menggunakan kamera dinocapture yang telah disambungkan dengan komputer.

Tabel 1. Hasil uji aktivitas ekstrak biji kebiul terhadap penggumpalan sel darah merah manusia dalam kondisi patologis

\begin{tabular}{|c|c|c|c|c|c|c|}
\hline \multirow{2}{*}{ Penyakit } & \multirow{2}{*}{$\begin{array}{l}\text { Gol. } \\
\text { Darah }\end{array}$} & \multicolumn{5}{|c|}{ Pengulangan } \\
\hline & & 1 & 2 & 3 & 4 & 5 \\
\hline Malaria & B & - & - & - & - & - \\
\hline Diabetes & B & - & - & - & - & - \\
\hline Hipertensi & A & + & + & + & + & + \\
\hline Asam urat & A & - & - & - & - & - \\
\hline
\end{tabular}

Tabel 1 terlihat bahwa penggumpalan sel darah merah setelah penambahan ekstrak biji kebiul hanya pada penyakit hipertensi 
golongan darah A saja. Terjadi penggumpalan disebabkan di dalam ekstrak biji kebiul mengandung lektin. Lektin dapat menyebabkan penggumpalan sel darah merah (fitohemaglutinin) karena dapat mengikat gugus sakarida pada permukaan sel darah merah. Jika antar kedua molekul saling berkaitan, maka sel-sel darah akan menggumpal yang merupakan proses aglutinasi (Guyton dan Hall, 1997).

Pengaglutinasian golongan darah A dapat terjadi jika bereaksi dengan antibody $\alpha$ (a). Lektin biji J. Multifida L. yang hanya mengaglutinasi darah golongan A adalah lektin yang hanya membawa sifat antibody $\alpha$ (a) saja. Maknanya ekstrak biji J. Multifida $L$ dapat digunakan untuk menguji golongan darah A yang sehat, karena spesifik terhadap antibody $\alpha$ (a). Darah golongan darah A akan mengaglutinasi jika bereaksi dengan antibody $\alpha$ (a) tersebut (Diniah, 2012).

Berdasarkan hasil penelitian diperoleh contoh foto darah yang dapat menggumpal dan yang tidak menggumpal.
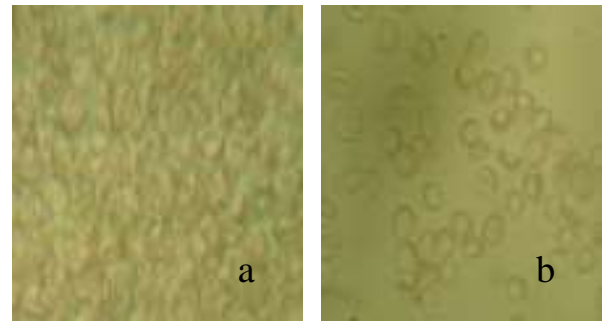

Gambar 1. a. sel darah A Hipertensi yang menggumpal, b. sel darah A Asam urat yang tidak menggumpal

Pembekuan darah (koagulasi) adalah suatu proses kimiawi dimana plasma dari protein-protein berinteraksi untuk mengubah molekul protein plasma besar yang larut, berupa fibrinogen menjadi gel stabil yang tidak larut yang disebut fibrin.

Tidak menggumpalnya sel darah merah golongan A pada penderita asam urat disebabkan lektin pada biji kebiul dapat terhalangi oleh adanya sisa metabolisme zat purin (protein plasma). Untuk golongan darah B penderita malaria sel darah merah terinfeksi oleh parasit-parasit, sehingga proses hemaglutinasi terhalangi, demikian juga golongan darah B penderita diabetes karena kadar glukosa dalam aliran darah sangat tinggi menyebabkan lektin biji kebiul tidak mampu menghemaglutinasi. Lektin yang tidak spesifik pada gugus sakarida tertentu dari golongan darah akan dapat menggumpalkan sel-sel darah merah. Karena lektin akan bereaksi dengan oligosakarida yang terdapat pada permukaan sel darah merah (Muslim, 1999). Penyusun sakarida pada glikoprotein adalah glukosa, galaktosa, mannosa, fruktosa, asetil glukosamin, asetil galaktosamin, asam asetilneuralminat, arulinosa dan Xibosa (Sugiri, 1992).

Terjadinya penggumpalan sel darah merah disebabkan polimerisasi molekulmolekul fibrinogen menjadi benang-benang fibrin dibantu oleh trombin dengan cara melepaskan empat peptida yang mempunyai berat molekul rendah dari setiap molekul fibrinogen, sehingga membentuk molekul fibrin monomer yang mempunyai kemampuan otomatis untuk berpolimerisasi dengan molekul fibrin monomer lainnya melalui ikatan hidrogen non kovalen lemah serta menjadi benang-benang fibrin yang tidak terikat kuat antara satu dengan yang lainnya. Oleh karena itu diperlukan faktor stabilisasi fibrin dan mengaktifkan faktor tersebut.

Hasil uji aktivitas lektin biji kebiul terhadap penggumpalan sel darah merah manusia hipertensi golongan $A$

Ekstrak yang diperoleh dari hasil ekstraksi adalah sebanyak 5,438 gram dan dibuat dalam 4 konsentrasi yaitu $2 \%, 4 \%, 6 \%$ dan $8 \%$. Masing-masing konsentrasi tersebut digunakan untuk pengujian aktivitas ekstrak biji kebiul terhadap kecepatan penggumpalan sel darah merah manusia hipertensi golongan A. Pada tabel 2 disajikan hasil uji aktivitas lektin biji kebiul terhadap kecepatan penggumpalan sel darah merah manusia hipertensi golongan $\mathrm{A}$.

Tabel 2. Hasil uji aktivitas lektin biji kebiul terhadap kecepatan penggumpalan sel darah merah manusia hipertensi golongan A

\begin{tabular}{lccrl}
\hline No & Konsentrasi & $\begin{array}{c}\text { Pengulan } \\
\text { gan }\end{array}$ & $\begin{array}{c}\text { Rata-rata } \pm \\
\text { SD } \\
\text { (satuan Detik) }\end{array}$ & $\begin{array}{c}\text { Kecepatan } \\
(\mathrm{v}=[\mathrm{]} / \mathrm{t})\end{array}$ \\
\hline 1. & $\mathrm{P}(1) 2 \%$ & $5 \mathrm{kali}$ & $136.6 \pm 61,78$ & 0,015 \\
2. & $\mathrm{P}(2) 4 \%$ & $5 \mathrm{kali}$ & $129.6 \pm 58,11$ & 0,031 \\
3. & $\mathrm{P}(3) 6 \%$ & $5 \mathrm{kali}$ & $86.6 \pm 39,30$ & 0,069 \\
4. & $\mathrm{P}(4) 8 \%$ & 5 kali & $56 \pm 25,10$ & 0,143 \\
\hline
\end{tabular}

Berdasarkan Tabel 2 dapat dilihat bahwa aktivitas lektin biji kebiul terhadap 
kecepatan penggumpalan sel darah merah manusia hipertensi golongan darah A untuk konsentrasi $2 \%$ didapatkan kecepatan penggumpalan sel darah merah manusia hipertensi golongan A sebesar 0,015 pada konsentrasi $4 \%$ kecepatan penggumpalan sel darah merah manusia hipertensi golongan $\mathrm{A}$ sebesar 0,031 pada konsentrasi 6\% kecepatan penggumpalan sel darah merah manusia hipertensi golongan A sebesar 0,069 dan konsentrasi $8 \%$ kecepatan penggumpalan sel darah merah manusia hipertensi golongan $\mathrm{A}$ sebesar 0,143. Pada konsentrasi 8\% kecepatan penggumpalan sel darah merah manusia hipertensi golongan darah A paling besar. Berarti aktivitas ekstrak biji kebiul untuk menggumpalkan sel darah merah golongan A sangat dipengaruhi oleh besarnya konsentrasi.

Salah satu faktor yang mempengaruhi perubahan waktu aglutinasi adalah konsentrasi ekstrak protein yang mengandung lektin. Semakin tinggi konsentrasi ekstrak biji kebiul maka semakin cepat terjadinya penggumpalan sel darah merah. Hal ini disebabkan pada ekstrak biji kebiul mengandung lektin yang berpengaruh terhadap penggumpalan sel darah merah manusia golongan $\mathrm{A}$.

Penentuan massa molekul relatif lektin yang terkandung dalam ekstrak biji kebiul

Untuk mengetahui berat molekul protein yang berperilaku sebagai lektin dilakukan analisis menggunakan Sodium Dodecyl SulfatPolyacrylamide Gel Elektrophoresis 1 Dimensi (SDS PAGE 1-D). Elektroforesis akan menghasilkan profil pita-pita protein yang terpisah berdasarkan berat molekulnya.

Bahan yang dipakai sebagai standar (STD) pada elektroforesis SDS PAGE 1-D adalah Pure Whey $141 \mathrm{KDa}$, lactoperoxidase $75 \mathrm{kDa}$, casein $35 \mathrm{KDa}, \beta$-Lactoglobulin 18 KDa.

Gambar 2 menunjukkan bahwa pita hanya tampak jelas pada sampel c dan d terlihat 3 pita yang jelas tampak. pada sampel b tidak tampak adanya pita. secara umum pada c dan d diperoleh 3 pita protein yang berada pada kisaran berat molekul 80, 128, dan 144 KDa. Pada biji kebiul mempunyai berat molekul dengan rentang sekitar 128-144 KDa. Hal ini sesuai dengan pendapat (Murray,1999) yang menyatakan lektin merupakan suatu glikogen yang memiliki berat molekul antara 36.000 - 150.000 Dalton.

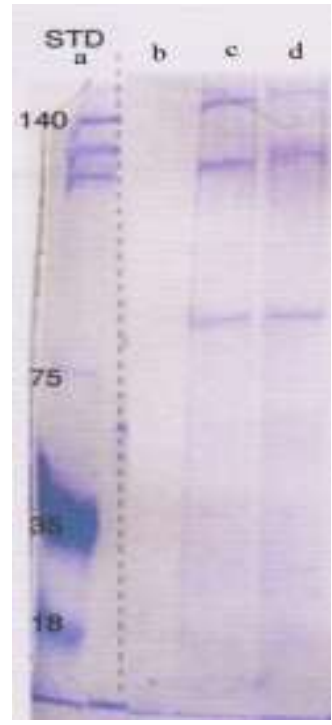

Gambar 2. Hasil Analis Elektroforesis SDS PAGE a. standar pure Whey, b. Lektin biji kebiul yang digunakan dalam uji, c dan d. Biji kebiul segar

Tebal tipisnya pita yang terbentuk dari pita protein menunjukkan kandungan atau banyaknya protein yang mempunyai berat molekul yang sama yang berada pada posisi pita yang sama. Bentuk ini sejalan dengan prinsip pergerakan molekul bermuatan, yakni molekul bermuatan dapat bergerak bebas di bawah pengaruh medan listrik, molekul dengan muatan dan ukuran yang sama akan terakumulasi pada zona atau pita yang sama atau berdekatan (Soedarmadji, 1996).

\section{Hasil Penelitian Pembelajaran}

Data penelitian adalah berupa hasil belajar biokimia dalam bentuk nilai pre tes dan pos tes untuk kedua kelompok penelitian yaitu data hasil belajar kelas eksperimen dan data hasil belajar kelas kontrol. Statistik deskriptif data hasil penelitian kelompok perlakuan (eksperimen) dan kelompok kontrol seperti terlihat pada tabel 3 yang merupakan hasil print statistik deskriptif dari computer.

Dari hasil tes kelas eksperimen mahasiswa yang diajar menggunakan modul di perolehan nilai rata-rata pre tes 36,67 dengan simpangan baku10,29 sedangkan nilai rata rata postes 95 dengan simpangan baku 7,07. Untuk kelas kontrol nilai rata-rata pre tes 29,41 dengan simpangan baku 9,66 dan rata rata pos tes 69,41 dengan simpangan baku 9,66. Hal ini menunjukkan bahwa pengetahuan mahasiswa yang diajar dengan modul tentang uji aktivitas lektin biji kebiul terhadap kecepatan 
pengumpulan sel darah merah manusia hipertensi golongan A lebih tinggi dari pada mahasiswa kelas kontrol yang diajar tanpa modul. Hasil penilaian lembar observasi terhadap aktivitas mahasiswa kelas eksperimen dengan rata-rata 35,5 dengan kategori baik, seperti tabel kelas eksperimen.

Tabel 3. Statistik Deskriptif Data Pre Tes

\begin{tabular}{|l|r|r|}
\hline & $\begin{array}{c}\text { Pretes Kelas } \\
\text { eksperimen }\end{array}$ & $\begin{array}{c}\text { Pretes kelas } \\
\text { kontrol }\end{array}$ \\
\hline N Valid $\quad$ Missing & 18 & 17 \\
Mean & 17 & 18 \\
Std. Error of & 36.67 & 29.41 \\
Mean & 2.425 & 2.344 \\
Median & 40.00 & 30.00 \\
Mode & 40 & 30 \\
Std. & 10.290 & 9.663 \\
Deviation & 105.882 & 93.382 \\
Variance & 30 & 30 \\
Range & 20 & 10 \\
Minimum & 50 & 40 \\
Maximum &
\end{tabular}

Tabel 4. Statistik Deskriptif Data Pos Tes

\begin{tabular}{|l|r|r|}
\hline & $\begin{array}{r}\text { Postes kelas } \\
\text { eksperimen }\end{array}$ & $\begin{array}{c}\text { Postes } \\
\text { kelas } \\
\text { kontrol }\end{array}$ \\
\hline N Valid & 18 & 17 \\
Mean $\quad$ Missing & 17 & 18 \\
Std. Error of Mean & 95.00 & 69.41 \\
Median & 1.667 & 2.344 \\
Mode & 100.00 & 70.00 \\
Std. Deviation & 100 & 70 \\
Variance & 7.071 & 9.663 \\
Range & 50.000 & 93.382 \\
Minimum & 20 & 40 \\
Maximum & 80 & 40 \\
\hline
\end{tabular}

Tabel 5. Hasil Penilaian Lembar observasi Kelas Eksperimen.

\begin{tabular}{|c|c|c|c|}
\hline Pengamat & Skor & Kriteria & $\begin{array}{c}\text { Skor } \\
\text { Rata-rata }\end{array}$ \\
\hline Pengamat 1 & 36 & Baik & \multirow{2}{*}{35,5} \\
\hline Pengamat 2 & 35 & Baik & \\
\hline
\end{tabular}

Sedangkan hasil penilaian lembar observasi terhadap aktivitas mahasiswa kelas kontrol dengan rata-rata 32 dengan kategori baik, seperti tabel kelas kontrol.
Tabel 6. Hasil Penilaian Lembar observasi Kelas Kontrol.

\begin{tabular}{|c|c|c|c|}
\hline Pengamat & Skor & Kriteria & $\begin{array}{c}\text { Skor } \\
\text { Rata- } \\
\text { rata }\end{array}$ \\
\hline Pengamat 1 & 33 & Baik & \multirow{2}{*}{32} \\
\hline Pengamat 2 & 31 & Baik & \\
\hline
\end{tabular}

\section{KESIMPULAN}

Pengujian menggunakan elektroforesis SDS PAGE 1 Dimensi membuktikan bahwa terdapat 3 pita protein yang berada pada kisaran berat molekul 80,128, dan 144 KDa. Lektin biji kebiul dapat menggumpalkan sel darah merah manusia hipertensi golongan A. Perbadaan konsentrasi berpengaruh terhadap kecepatan penggumpalan. Semakin tinggi konsentrasi lektin pada biji kebiul, semakin cepat terjadinya penggumpalan. Sebaliknya, semakin rendah konsentrasi lektin pada biji kebiul, semakin lambat terjadinya penggumpalan. Terdapat perbedaan hasil belajar mahasiswa tentang protein pada mahasiswa yang diajarkan dengan modul dan yang diajarkan tanpa Modul di Sekolah Tinggi Keguruan dan Ilmu Pendidikan Persatuan Guru Republik Indonesia (STKIP-PGRI) Lubuklinggau Prodi Biologi Semester IV Angkatan 2011. Rata-rata nilai pos tes kelas eksperimen 95 dan kelas kontrol 69,41.

\section{DAFTAR PUSTAKA}

Alroy, J., Ucci, AA., Perierra MEA. 1988. Lectin Histochemistry: an Update Advances in Immunohistochemistry. Ed.RA De Lellis. New York: Raven Press NY.

Diniah. 2012. Uji aktifitas Biji Jatropha multifida L. Terhadap Kecepatan Penggumpalan sel Darah Merah serta Implementasinya pada pembelajaran dengan Media Powerpoint Beranimasi. [Tesis] Bengkulu: Universitas Bengkulu.

Gegenheimer, P. 1990. Preparation of Extract From Plants. In Guide Protein Purification (Ed. M. P. Deutscher). San Diego: Academic Press, Inc.

Guyton, A dan Hall, J.E. 1997. Buku Ajar Fisiologi Kedokteran. Edisi 9. Jakarta: Penerbit EGC.

Latifah, N., Sundaryono, A., \& Elvia, R. 2017. Produksi Biofuel Dari Limbah Cpo 
Dengan Katalis Berbasis Titanium Oksida Dan Implementasinya Pada Pembelajaran Kimia. PENDIPA Journal of Science Education. 1(1).

Murray, R.K. 1999. Biokimia Edisi 24. Jakarta: Penerbit EGC.

Muslim, C. 1999. Macam bahan baracun lantinutrisi di dalam bahan makanan nabati Alternatif di Musim Krisis ekonomi. Bengkulu: Makalah seminar Regional LPIU-ABD, Februari 1999.
Soedarmadji, S. 1996. Teknik analisa Biokimiawi, Edisi Pertama. Yogyakarta: Liberty.

Sugiri, N. 1992. Biologi Sel Vol. 1. Departemen Pendidikan dan Kebudayaan Direktorat Jendral Pendidikan Tinggi. Bogor: Pusat Antar Universitas Pangan dan Gizi, Institut Pertanian Bogor. 